\title{
KEBIJAKAN PENUNDAAN SEMENTARA PENGIRIMAN TAHANAN DIMASA PANDEMI COVID-19
}

\author{
${ }^{1}$ Fitri Ningsih, ${ }^{2}$ Romi Asmara, ${ }^{2}$ Husni \\ e-mail : fitri.170510008@mhs.unimal.ac.id \\ ${ }^{1}$ Mahasiswa Fakultas Hukum Universitas Malikussaleh \\ ${ }^{2}$ Dosen Fakultas Hukum Universitas Malikussaleh
}

\begin{abstract}
Detention is a prerogative (absolute) owned by investigators, public prosecutors and judges in accordance with their respective stages of examination based on the provisions contained in the Criminal Procedure Code. While the placement of detainees is regulated in Government Regulation Number 27 of 1983 concerning the Implementation of the Criminal Procedure Code, but during this COVID-19 pandemic, the Minister of Law and Human Rights has issued a Circular Number: M.HH.PK.01.01.01-04 regarding the temporary postponement of shipments. detainees into the Rutan / Prison as a way of anticipating the spread of the COVID-19 virus. This study discusses how the policy of delaying the delivery of prisoners during the COVID-19 pandemic and what are the obstacles in delaying the delivery of prisoners to the Correctional Institution (Lapas). The purpose of this study was to find out about the temporary delay in sending prisoners during the COVID-19 pandemic and to find out the obstacles in implementing the policy at the Class II A Lhokseumawe Penitentiary. Using the type of empirical legal research, which is sourced from primary data and secondary data. This research is classified as a qualitative data type, namely by managing primary data sourced from the Lhokseumawe Resort Police, the Lhokseumawe District Attorney and the Class II A Lhokseumawe prison and 2 (two) prisoners who received a policy of temporarily delaying the delivery of prisoners to prisons. The results of this paper show that: 1) The policy on delaying the delivery of prisoners to the Class II A Lhokseumawe Prison has been implemented since October 15, 2020 based on the Instruction Letter of the Director General of Corrections Number: PAS-OT.02.02.25, in which it is explained specifically how prisoners who may or may not be sent to prison. 2) While the obstacle in implementing the policy is the accumulation of detainees in the Detention Cell at the Lhokseumawe Police Office, there is no request for a transfer of detention or detention and the construction of a new prison has not yet been implemented. Suggestions to the government for the future include the examination judge system in the Draft Criminal Procedure Code and accelerate the construction of new prisons.
\end{abstract}

Keywords: Policy, Detention, Covid 19 


\section{PENDAHULUAN}

Seluruh dunia dan termasuk Indonesia sedang menghadapi yang namanya virus corona (COVID-19), dan menurut WHO (World Health Organization) virus Corona merupakan keluarga besar virus yang menyebabkan penyakit pada hewan atau manusia dan menyebabkan infeksi pernapasan mulai dari flu biasa hingga yang lebih parah seperti Middle East Respiratory (MERS) dan Severe Acute Respitatory Syndrome (SARS). (Arief, 2020)

Di Indonesia kasus pertama mengenai virus corona (COVID-19) terkonfirmasi pada tanggal 2 Maret 2020, yang langsung diumumkan oleh Presiden Republik Indonesia (Jokowi), dimana ada 2 (dua) orang Indonesia yang positif terjangkit virus corona (COVID-19) yakni ibu dan anak yang berusia 31 tahun dan 64 tahun. (detikcomdetikNews, 2020)

Salah satu cara dalam pencegahan penyebaran virus ini adalah dengan melakukan jaga jarak (social distanching), namun tidak semua himbauan untuk menjaga jarak dapat untuk dilaksanakan, apalagi di dalam Ruan dan Lapas. Dimana kedua tempat tersebut seringkali banyak yang mengalami kelebihan kapasitas (overcrowding), dengan kenyataan terebut bagaimana himbauan untuk melaksanakan jaga jarak (social distanching) dapat untuk dilakukan. Pada tanggal 24 Maret 2020 pemerintah melalui Menteri Hukum dan HAM telah mengeluarkan Surat Edaran Tentang penundaan sementara penerimaan tahanan baru ke dalam Rutan/Lapas sampai batas waktu yang akan ditentukan. Dimana ini dilakukan sebagai salah satu cara pencegahan penyebaran virus COVID-19 itu sendiri.

Tahanan merupakan seseorang yang berada dalam masa penahanan, dan penahanan sendiri merupakan penempatan tersangka atau terdakwa ditempat tertentu oleh penyidik, penuntut umum dan hakim dengan penetapannya, dalam hal dan menurut cara yang diatur dalam undang-undang ini (Pasal 1 angka 21 KUHAP). Mengenai Penempatan tahanan sendiri merupakan hak mutlak yang dimiliki penyidik, penuntut umum ataupun hakim sesuai dengan proses pemeriksaannya masing-masing, sedangkan Penempatan tahanan berdasarkan Pasal 19 ayat (1) Peraturan Pemerintah Nomor 27 tahun 1983 dijelaskan tahanan yang masih dalam proses penyidikan, penuntutan, pemeriksaan di pengadilan negeri, pengadilan tinggi dan mahkamah agung ditempatkan di Rumah Tahanan Negara (Rutan). Dalam hal belum ada Rutan atau Rutan yang ada mengalami kelebihan kapasitas maka tersangka atau terdakwa dapat dititipkan di Lembaga Pemasyarakatan (Lapas). Dengan adanya Surat Edaran dari Menteri Hukum dan HAM tersebut, maka tersangka atau terdakwa selama masa pandemi COVID-19 tetap dititipkan di Kantor Kepolisian.

Istilah kebijakan berasal dari bahasa Inggris yaitu Policy atau dalam bahasa Belanda-nya Politiek yang secara umum dapat diartikan sebagai prinsip-prinsip umum yang fungsinya untuk mengarahkan pemerintah termasuk pula aparat penegak hukum dalam mengelola, mengatur, atau menyelesaikan urusan-urusan publik, masalahmasalah masyarakat atau bidang-bidang penyusunan peraturan perundang-undangan dan mengaplikasikan hukum atau peraturan, dengan tujuan yang mengarah pada upaya 
mewujudkan kesejahteraan atau kemakmuran masyarakat (warga negara). Berbicara mengenai kebijakan maka tidak luput dari Istilah kebijakan hukum pidana itu sendiri maka pengertian kebijakan hukum pidana merupakan bagian daripada politik kriminal (criminal police) usaha dan kebijakan untuk membuat peraturan hukum pidana yang baik serta pada hakikatnya tidak dapat dilepaskan dari tujuan penanggulangan kejahatan. (Nawawi, 2010)

Penundaan sementara pengiriman tahanan dapat diartikan sebagai suatu proses pengunduran waktu pengiriman tahanan baik itu bagi tersangka ataupun terdakwa, penundaan pengiriman ini dilakukan dengan berbagai sebab dan alasan dan akan dilaksanakan pada lain waktu dengan kondisi yang memungkinkan untuk dilakukan atau dilaksanakannya pengiriman tahanan ke Rutan/Lapas. Sementara pengiriman ke Lapas dilakukan peundaan maka tahanan akan ditempatkan di Kantor Kepolisian.

Sebelum munculnya pandemi COVID-19 penahanan dan pemenjaraan secara global selalu berhadapan dengan berbagai isu, terutama kelebihan kapasitas (overcrowding) dan pemenuhan hak minimum untuk tahanan dan narapidana. Apalagi selama masa pademi ini berlangsung bukan hanya kelebihan kapasitas saja yang menjadi problematika akan tetapi juga meningkatnya angka kejahatan yang menyebakan bertambahnya jumlah tahanan, sedangkan Rutan dan Lapas tidak mampu untuk menerapkan kebijakan social distanching.

\section{METODE PENELITIAN}

Adapun metode penelitian yang digunakan dalam penelitian ini yaitu penelitian yuridis empiris atau yang lebih dikenal dengan penelitian lapangan, data yang didapat melalui kegiatan observasi dan wawancara serta didukung oleh pengumpulan data secara kepustakaan. (Sugono, 2007) Peneliti menggunakan pendekatan kualitatif yang merupakan prosedur penelitian yang menghasilkan data deskriptif berupa kata-kata tertulis atau tulisan dari orang-orang dan perilaku yang diamati dan berupaya untuk mencari makna atau "verstehen" dikembangkan berdasarkan hasil penelitian dilapangan yang bersumber pada data primer (responden dan informan). Penelitian ini juga bersifat deskriptif dan analisis, yang merupakan studi untuk menemukan fakta dengan interprestasi yang tepat.

Sember data penelitian didapatkan dari sumber data primer yang diperoleh dilapangan melalui proses wawancara kepada respoden dan informan. Dan data sekunder atau data penunjang dalam penelitian ini yaitu melalui studi kepustakaan dengan cara pengumpulan data dari berbagai sumber normatif yang berkaitan dengan permasalahan yang sedang diteliti, oleh karena itu teknik pengumpulan data yang digunakan yaitu dengan mengumpulkan data, baik itu dilakukan secara dokumen/literatur ataupun wawancara langsung ke lapangan. Pengumpulan data juga dilakukan melalui peraturan perundang-undangan, serta klasifikasi dan sistematisasi bahan hukum sesuai dengan permasalahan penelitian. Studi kepustakaan juga dapat dilakukan dengan cara membaca, menelaah, serta mencatat ulasan bahan-bahan pustaka.

Dalam penelitian ini data primer diambil di 3 (tiga) tempat pada wilayah hukum yang sama, yaitu di Kantor Kepolisian Resor Lhokseumawe, Kantor Kejaksaan Negeri 
Lhokseumawe dan Lapas Kelas II A Lhokseumawe. Pengambilan lokasi ini dengan pertimbangan bahwa sumber data di lokasi tersebut memungkinkan untuk dilakukan penelitian yang berkaitan dengan kebijakan penundaan semetara pengiriman tahanan dimasa pandemi COVID-19.

\section{HASIL PENELITIAN DAN PEMBAHASAN}

\section{A. Kebijakan Penundaan Sementara Pengiriman Tahanan Dimasa Pandemi COVID-19}

Penempatan tahanan di dalam Rutan berdasarkan Peraturan Pemerintah Tahun 1983 Tentang Pelaksanan KUHAP, pada Pasal 19 Ayat (2) dijelaskan bahwa penempatan tahanan harus dipisahkan berdasarkan tahapan pemeriksaannya. Namun selama masa pandemi COVID-19 tahanan dititipkan pada kantor kepolisian dan ditempatkan dalam satu tempat yang sama, baik itu tahanan penyidik ataupun tahanan penuntut umum, tentu saja hal ini bertentangan dengan peraturan yang ada dalam KUHAP.

\section{Ketentuan KUHAP Tentang Penempatan Tahanan}

Dalam Undang-Undang Nomor 8 Tahun 1981 tentang KUHAP memang mengatur tentang penahanan baik itu tata cara penahanan, jenis-jenis penahanan dan siapa sajakah yang berhak untuk melakukan suatu penahanan, namun tidak ada diatur tentang penundaan sementara pengiriman tahanan ke Rutan/Lapas dimasa pandemi COVID-19, penundaan ini bertentangan dengan Pasal 1 angka 21 KUHAP.

Mengenai penempatan tahanan sendiri merupakan hak prerogatif (hak mutlak) dari seorang penyidik, penuntut umum dan hakim sesuai dengan tahapan proses pemeriksaannya masing-masing. Artinya penempatan tahanan bisa saja dilakukan di Rutan, Lapas, Kantor Kepolisian, Kantor Kejaksaan ataupun Rumah Sakit sesuai dengan ketentuan dari Pasal 22 ayat (1) KUHAP, Sedangkan dalam Surat Edaran Menteri Hukum dan HAM "Tentang Penundaan Sementara Pengiriman Tahanan Ke Rutan/Lapas Di Lingkungan Kementerian Hukum Dan Ham”, yang salah satu isinya berisi tentang penundaan penerimaan tahanan baru ke dalam Rutan/Lapas. Tentu saja hal tersebut dapat menimbulkan pertentangan dengan peraturan perundang-undangan yang ada sebelumnya. Mengenai kebijakan penundaan sementara pengiriman tahanan dimasa pandemi COVID-19 hal ini merupakan hal yang baru dalam peraturan perundang-undangan yang ada di Indonesia, karena seperti yang diketahui bahwa hal ini terjadi dikarenakan adanya sesuatu yang sangat mendesak, sehingga inilah yang menyebabkan perlu dibuatnya mengenai kebijakan penundaan sementara pengiriman tahanan dimasa pandemi COVID-19 sekarang ini, dan diharapkan dapat mencegah lajunya perkembangan dan penyebarluasaan virus COVID-19 yang ada di Indonesia, khususnya di Lingkungan Rutan/Lapas.

Dalam KUHAP, Menteri Hukum dan HAM tidak memiliki kewenangan baik itu untuk melarang ataupun menentukan tidaknya untuk dilakukan suatu penahanan, serta untuk mengatur dimana akan dilakukannya suatu penahanan, karena sekali lagi perlu ditegaskan bahwa berkaitan dengan penahanan itu merupakan suatu kewenangan yang 
hanya dimiliki oleh penyidik, penuntut umum serta hakim. Namun Menteri Hukum dan HAM dapat memberikan suatu rekomendasi ataupun masukan sehingga dapat dipertimbangkan oleh para aparatur penegak hukum supaya tidak dilakukan penahanan untuk masa-masa seperti sekarang (pandemi COVID-19) ataupun untuk dilakukannya pengalihan jenis tahanan sesuai dengan jenis-jenis penahanan yang ada pada Pasal 22 KUHAP, dengan tidak adanya pengaturan di dalam KUHAP mengenai keadaan yang mendesak seperti keadaan sekarang (pandemi COVID-19) jelas saja diperlukan peraturan yang baru, sehingga hal-hal yang seperti ini kedepannya tidak lagi menjadi suatu permasalahan.

Dalam hukum Indonesia (hukum positif) ada beberapa prinsip umum dalam berlakunya sebuah hukum (aturan) antara lain sebagai berikut: (Safudin, 2017).

a) Lex Posterior Derogat Legi Priori

b) Lex Specialis Derogat Legi Generalis

c) Lex Superior Derogat Legi Inferior

Dari ketiga asas (prinsip-prinsip) berlakunya suatu peraturan perundang-undangan tersebut dapat dilihat bahwasanya Surat Edaran Menteri Hukum dan HAM tidak ada yang termasuk dalam ke tiga asas diatas, namun dalam keadaan yang ikhwal (keadaan yang mendesak), maka kebijakan mengenai penundaan sementara pengiriman tahanan ke dalam Rutan/Lapas bisa dikatakan sebagai Lex Spacialis, dan perlu untuk dilakukan atau dilaksanakan, hal ini dilakukan sebagai upaya antisipasi dalam keadaan mendesak (pandemi COVID-19). Namun berlakunya Surat Edaran tersebut sebagai lex specialis hanya selama masa pandemi COVID-19 ini berlangsung, jika keadaan sudah membaik (normal) maka Surat Edaran tersebut tidak akan dianggap lex specialis lagi dan tentu saja Surat Edaran tersebut akan ditarik kembali oleh pemerintah.

\section{Rutan Dan Lapas Yang Ada Di Provinsi Aceh}

Berdasarkan Wilayah Hukum KANWIL Kementerian Hukum dan HAM Provinsi Aceh maka jumlah Rutan atau Lapas yang ada berjumlah sebagai berikut:

Tabel I Daftar Rutan dan Lapas yang ada di Provinsi Aceh

\begin{tabular}{|c|c|c|c|c|c|}
\hline No & Rutan & Lapas & LPKA & $\begin{array}{l}\text { Lapas } \\
\text { Perempuan }\end{array}$ & Lapas Narkotika \\
\hline 1 & $\begin{array}{l}\text { Rutan Kelas II } \\
\text { Banda Aceh }\end{array}$ & $\begin{array}{l}\text { Lapas Kelas II A } \\
\text { Banda Aceh }\end{array}$ & $\begin{array}{l}\text { LPKA } \\
\text { Kelas II A } \\
\text { Banda } \\
\text { Aceh }\end{array}$ & $\begin{array}{l}\text { Lapas Perempuan } \\
\text { Kelas II B Sigli }\end{array}$ & $\begin{array}{l}\text { Lapas Narkotika } \\
\text { Kelas II B Langsa }\end{array}$ \\
\hline 2 & $\begin{array}{l}\text { Rutan Kelas II } \\
\text { Bener Meriah }\end{array}$ & $\begin{array}{l}\text { Lapas Kelas II A } \\
\text { Lhokseumawe }\end{array}$ & & & \\
\hline 3 & $\begin{array}{l}\text { Rutan Kelas II } \\
\text { Jantho }\end{array}$ & $\begin{array}{l}\text { Lapas Kelas II B } \\
\text { Bireun }\end{array}$ & & & \\
\hline 4 & $\begin{array}{l}\text { Rutan Kelas II } \\
\text { B Sabang }\end{array}$ & $\begin{array}{l}\text { Lapas Kelas II B } \\
\text { Blangkejeren }\end{array}$ & & & \\
\hline 5 & $\begin{array}{l}\text { Rutan Kelass } \\
\text { II Sigli }\end{array}$ & $\begin{array}{l}\text { Lapas Kelas II B } \\
\text { Blangpidie }\end{array}$ & & & \\
\hline 6 & $\begin{array}{l}\text { Rutan Kelas II } \\
\text { B Singkil }\end{array}$ & $\begin{array}{l}\text { Lapas Kelas II B } \\
\text { Idi }\end{array}$ & & & \\
\hline
\end{tabular}




\begin{tabular}{|l|l|l|l|l|l|}
\hline 7 & $\begin{array}{l}\text { Rutan Kelas II } \\
\text { B Takengon }\end{array}$ & $\begin{array}{l}\text { Lapas Kelas II B } \\
\text { Kota Bakti }\end{array}$ & & & \\
\hline 8 & $\begin{array}{l}\text { Rutan Kelas II } \\
\text { B Tapaktuan }\end{array}$ & $\begin{array}{l}\text { Lapas Kelas II B } \\
\text { Kuala Simpang }\end{array}$ & & & \\
\hline 9 & & $\begin{array}{l}\text { Lapas Kelas II B } \\
\text { Kutacane }\end{array}$ & & & \\
\hline 10 & & $\begin{array}{l}\text { Lapas Kelas II B } \\
\text { Langsa }\end{array}$ & & & \\
\hline 11 & & $\begin{array}{l}\text { Lapas Kelas II B } \\
\text { Lhoksukun }\end{array}$ & & & \\
\hline 12 & & $\begin{array}{l}\text { Lapas Kelas II B } \\
\text { Meulaboh }\end{array}$ & & & \\
\hline 13 & & $\begin{array}{l}\text { Lapas Kelas III B } \\
\text { Calang }\end{array}$ & & & \\
\hline 14 & & $\begin{array}{l}\text { Lapas Kelas III B } \\
\text { Lhok Nga }\end{array}$ & & & \\
\hline 15 & & $\begin{array}{l}\text { Lapas Kelas III B } \\
\text { Sinabang }\end{array}$ & & & \\
\hline
\end{tabular}

Sumber: Sistem Database Pemasyarakatan, smslap.ditjenpas.go.id 2021.

Dari daftar Rutan atau Lapas yang ada di Provinsi Aceh hampir seluruhnya mengalami kelebihan kapasitas (overcrowding). Dan selama masa pandemi ini salah satu Lapas yang menerapkan kebijakan penundaan sementara pengiriman tahanan adalah Lapas Kelas II A Lhokseumawe

Menurut Yusri, dijelaskan Lapas Lhokseumawe mulai memberlakukan kebijakan tersebut sejak tanggal 15 Oktober 2020. Hal ini berpedoman pada Surat Direktoriat Jenderal Pemasyarakatan Nomor: PAS-OT.02.02-25 Tentang Revisi 1 Pedoman COVID-19 di UPT Pemasyarakatan. Yang merupakan tindak lanjut dari Surat Edaran Menteri Hukum dan HAM mengenai kebijakan penundaan pengiriman tahanan. Hal ini juga didasarkan pada fakta bahwa cukup banyaknya tahanan yang terindikasi positif virus COVID-19, hal ini telah dilakukan cek baik itu secara Rapid tes maupun tes Swab. (Yusri, 2021)

Menindaklanjuti Surat Edaran Menteri Hukum dan HAM mengenai penundaan sementara pengiriman tahanan ke dalam Rutan/Lapas selama masa pandemi COVID-19, maka pada tanggal 02 April 2020 dikeluarkan Surat Edaran dari Direktoriat Jenderal Pemasyarakatan Nomor: PAS-PK.01.01.01-511 Tentang Registrasi dan Pemberian Makanan Tahanan (A2) Di Luar Rutan/Lapas/LPKA, yang isinya tentang:

1) Bahwa penundaan sementara penerimaan tahanan $A 2$, Tahanan $A 3$ dan tahanan yang sudah diputus oleh pengadilan dan memiliki kekuatan hukum tetap (inkracht) untuk dicatat pada registrasi di Lapas/Rutan/LPKA, sementara tahanan dititipkan kepada kepolisian, maka terkait makan dan minuman tahanan tersebut tetap menjadi tanggung jawab kepala Rutan/ Kepala Lapas/ Kepala LPKA selaku kuasa penggunaan Anggaran (KPA)

2) Besar nilai makan dan minum yang diberikan sama dengan yang diberikan kepada tahanan dan narapidana yang ada di Rutan/Lapas/LPKA 
3) Kepala Rutan/ Kepala Lapas/ Kepala LPKA segera melakukan koordinasi dengan kepala kepolisian Resort (Polres), Kepala Kejaksaan Negeri, dan Ketua Pengadilan Negeri terkait dengan mekanisme pemberian makan dan minum tahanan tersebut

4) Selanjutnya, Kepala Devisi Pemasyarakatan untuk melakukan monitering dan evaluasi pelaksaan pemberian makan dan minuman tahanan yang berada diluar Rutan/Lapas/LPKA dan menyampaikan laporan mingguan kepada Direktur Jenderal Pemasyarakatan.

Lalu pada tanggal 16 juni 2020 Direktoriat Jenderal Pemasyarakatan juga mengeluarkan Surat yang berisi tentang Penerimaan Tahanan Pengadilan (Tahanan A3) dengan ketentuan sebagai berikut:

1) Mempertimbangkan kapasitas blok/kamar isolasi yang dimiliki oleh Lapas/Rutan/LPKA

2) Tahanan yang diterima harus sudah dilakukan tes Rapid dengan hasil Non Reaktif oleh Jaksa (hasil tes Rapid dilampirkan)

3) Melakukan skrining suhu tubuh dan pemeriksaan kesehatan awal dan berskala

4) Melakukan komunikasi informasi edukasi (KIE) tentang perilaku hidup bersih dan sehat (PHBS)

5) Memberikan masker kain yang wajib dipakai

6) Memberikan informasi tentang kewajiban melaksanakan Physical Dan Social Distancing

7) Melakukan isolasi selama 14 (empat belas) hari, bila timbul gejala COVID-19 selama masa isolasi segera berkomunikasi dengan Dinas Kesehatan setempat untuk melakukan Tes PCR dan bila didapati hasil tes positif, segera dirujuk kerumah sakit rujukan COVID-19 setempat

8) Melaksanakan secara ketat 12 (dua belas) langkah pencegahan dan penanganan COVID-19.

Lalu pada tanggal 25 Agustus 2020 dikeluarkan juga Surat dari Direktoriat Jenderal Pemasyarakatan dengan Nomor: PAS-OT.02.02.25 Tentang Revisi 1 Pedoman COVID-19 di UPT Pemasyarakatan, yang berisikan tentang:

1) Belum diizinkan menerima Tahanan baru berstatus A1 (Tahanan Penyidik) dan A2 (Tahanan Jaksa) di Lapas, Rutan, LPKA penerimaan Tahanan baru hanya yang berstatus A3 (Tahanan Hakim) dan sudah bekekuatan hukum tetap (inkracht) dengan memperhatikan kapasitas pada ruang isolasi

2) Belum diizinkan untuk penyelenggaraan kunjungan dengan kontak langsung di Lapas, Rutan dan LPKA kunjungan dilakukan secara online/ virtual.

Juga terdapat surat-surat yang berhubungan dengan penundaan sementara pengiriman tahanan selama masa pandemi COVID-19, yang Pada tanggal 26 Maret 2020 juga dikeluarkan sebuah Surat Edaran Nomor: PAS-20.PR.01.01 Tahun 2020 Tentang Langkah Progresif Dalam Penanggulangan Penyebaran Virus COVID-19 Pada 
Unit Pelaksana Teknis Pemasyarakatan yang ditujukan kepada Kepala Kantor Wilayah Kementerian Hukum dan HAM RI, yang mana Surat Edaran ini berisi Upaya penanggulangan virus COVID-19, dan memastikan semua UPT Pemasyarakatan telah melaksanakan penanganan dengan perpedoman pada Surat Edaran Seketaris Jendral Nomor: SEK-02.OT.02.02 Tentang Pencegahan dan Penanganan COVID-19 di Lingkungan Kementerian Hukum dan HAM serta Intruksi Direktur Jendral Pemasyarakatan Nomor: PAS-08.OT.02.02 Tentang Pencegahan, Penanganan, Pengendalian dan Pemulihan COVID-19 Pada Unit Pelaksana Teknis Pemasyarakatan.

Lalu untuk wilayah Aceh sendiri Kementerian Hukum dan HAM Kantor Wilayah Aceh pada tanggal 20 Maret 2020 mengeluarkan sebuah surat yang ber Nomor: W1PK.01.01-086 dengan Perihal Pencegahan Penyebaran Wabah Virus COVID-19 ke dalam Lapas/Rutan, yang mana ada beberapa hal yang perlu untuk dipertimbangkan yang antara lain sebagai berikut:

1) Penundaan Penitipan Tahanan Baru

2) Penundaan Pelimpahan Perkara Baru

3) Penundaan Persidangan di Pengadilan

Surat ini ditujukan kepada Ketua Pengadilan Negeri Aceh, Kepala Kejaksaan Tinggi Aceh dan Kepada Kepala Kepolisian Daerah Aceh.

Direktoriat Jendral Pemasyarakatan pada tanggal 30 Mei 2020 Mengeluarkan Surat Edaran yang bernomor: PAS7.01.06.06-190 Tentang Kewajiban Pelaksanaan Protokol Kesehatan dalam Pandemi COVID-19. Yang mana Surat Edaran tersebut memuat beberapa hal atau ketentuan, yang antara lainnya sebagai berikut:

1) Mengingatkan Petugas Pemasyarakatan untuk mematuhi aturan protokol kesehatan dengan disiplin, dan menahan diri untuk tidak mudik dan melakukan pertemuan-pertemuan, berkerumunan dengan kontak pisik yang melanggar protokol kesehatan, mengingat Petugas Pemasyarakatan berfotensi untuk menularkan COVID-19 kepada Warga Binaan Pemasyarakatan di Lapas/Rutan, LPKA.

2) Semua orang yang akan memasuki UPT Pemasyarakatan dilakukan pemeriksaan suhu tubuh.

3) Pembatasan secara ketat keluar masuknya orang dan barang kedalam UPT Pemasyarakatan.

4) Kewajiban mencuci tangan sebelum masuk dan saat akan keluar dari UPT Pemasarakatan.

5) Kewajiban bagi semua orang untuk selalu menggunakan masker kain selama berada di dalam UPT Pemasyarakatan.

6) Pelaksanaan Physical dan Social Distancing antara sesama petugas, petugas dan WBP (Warga Binaan Pemasyarakatan) dan sesama WBP (Warga Binaan Pemasyarakatan).

7) Pelaksanaan isolasi bagi tahanan dan WBP (Warga Binaan Pemasyarakatan) yang terindikasi virus COVID-19. 
8) Pelaksanaan isolasi mandiri bagi petugas yang terindikasi virus COVID-19.

9) Berkoordinasi dengan dinas kesehatan dan rumah sakit rujukan COVID-19 setempat.

Dari Surat Edaran yang telah dikeluarkan oleh Direktoriat Jendral Pemasyarakatan yang ditujukan untuk semua Kepala UPT Pemasyarakatan seluruh Indonesia, bahwasanya untuk penerimaan tahanan baru ke dalam Rutan/Lapas maka diberlakukan beberapa hal dan juga diberlakukan beberapa kebijakan hal ini dilakukan dalam upaya pencegahan Virus COVID-19 di lingkungan UPT Pemasyarakat itu sendiri.

Tabel II Daftar Tahanan Kejaksaan Negeri Kota Lhokseumawe Yang Positif virus COVID-19 Dari Bulan April 2020 -Januari 2021

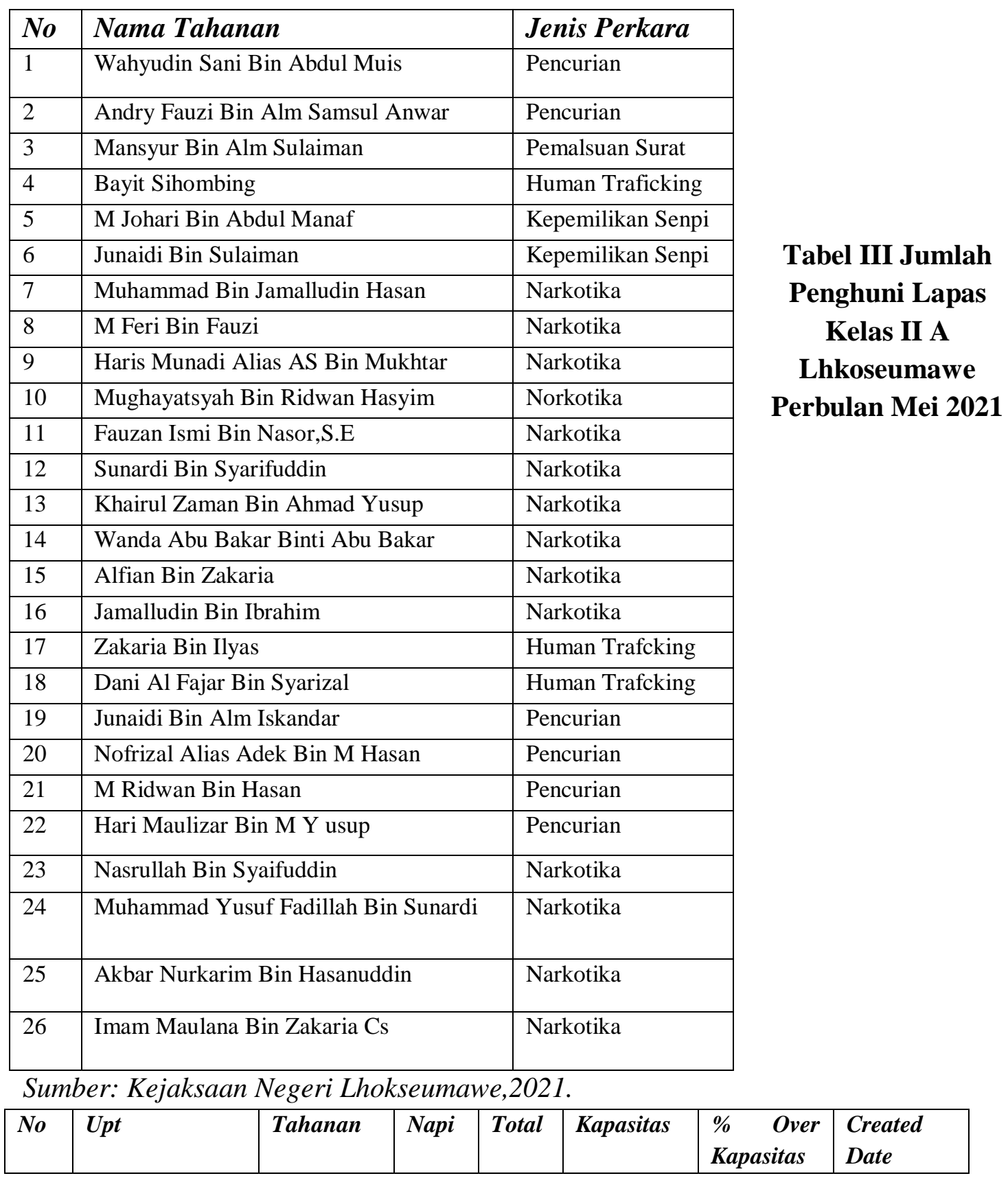




\begin{tabular}{|l|l|l|l|l|l|l|l|}
\hline 1 & $\begin{array}{l}\text { Lapas kelas II A } \\
\text { Lhokseumawe }\end{array}$ & 99 & 524 & 623 & 150 & 315 & $\begin{array}{l}2021-05- \\
25 \\
09: 10: 28\end{array}$ \\
\hline
\end{tabular}

Sumber: Sistem Database Pemasyarakatan, Smslap.ditjenpas.go.id, 2021.

Sedangkan data yang diperoleh dari Lapas Kelas II A Lhokseumawe menunjukkan banyaknya jumlah tahanan dengan status A1 dan A2 yang tidak di kirimkan ke dalam Lapas selama kebijakan tersebut diberlakukan:

1. bulan November : 16 tahanan

2. bulan Desember : 18 tahanan

3. bulan Januari : 12 tahanan

4. bulan Februari : 22 tahanan

5. bulan Maret : 12 tahanan

6. bulan April : 11 tahanan

7. bulan Mei : 3 tahanan

8. bulan Juni : 1 tahanan

B. Hambatan Dalam Penundaan Sementara Pengiriman Tahanan Ke Dalam Lembaga Pemasyarakatan.

1. Hambatan mengenai jumlah ruang tahanan/ ruang isolasi untuk penempatan tahanan.

Surat Edaran Menteri Hukum dan HAM tentang Penundaan sementara pengiriman tahanan dikeluarkan pada tanggal 24 Maret 2020, akan tetapi pelaksanaan dari penerapan Surat Edaran tersebut baru dilaksanakan di Lapas Lhokseumawe pada tanggal 15 Oktober 2020, hal ini merujuk pada Surat Edaran Direktur Jenderal Pemasyarakatan Nomor:PAS-OT.02.02.25 Tentang Revisi 1 Pedoman COVID-19 di UPT Pemasyarakatan, dimana dalam Surat Edaran tersebut dijelaskan secara spesifik tahanan yang bagaimana yang tidak boleh dikirimkan kedalam Lapas selama masa pandemi COVID-19. Tentu saja hal ini merujuk pada fakta dilapangan bahwa daya tampung Lapas yang terbatas, dan adanya beberapa Lapas yang dilakukan Lockdown, serta data yang menunjukan peningkatan jumlah tahanan selama masa pandemi.

Menurut Zahabi, Kantor Kepolisian Resor Lhokseumawe selama masa pandemi COVID-19, yang dijadikan sebagai salah satu tempat penitipan tahanan dengan status tahanan A1 dan tahanan A2, hal ini terjadi karena tahanan A1 dan A2 dilarang untuk dikirimkan ke dalam Lapas untuk sementara waktu sampai batas waktu yang belum ditentukan. Hal ini jelas menimbulkan sebuah permasalahan karena Kantor Polres Lhokseumawe terkendala dengan jumlah ruang tahanan yang ada, sedangkan jumlah tahanan yang setiap bulannya terus bertambah, walaupun tahanan yang telah beralih dari tahanan A2 menjadi tahanan A3 sudah dikirimkan ke dalam Lapas, tetap saja Polres Lhokseumawe kewalahan dalam penanganan penempatan tahanan selama masa pandemi. Hal inilah yang menyebabkan digabungkannya tahanan A1 dan A2 dalam tempat yang sama, dan seharusnya dalam 1 (satu) sel tahanan ditempatkan untuk kapasitas 10 orang tahanan malah ditempatkan hampir 15-20 tahanan. (Zahabi, 2021) 
Menurut Ayu Miranda, ia menjelaskan bahwa selama ditahan di sel tahanan Kantor Kepolisian Resor Lhokseumawe dan menjadi tahanan penyidik, ia sudah beberapa kali menjalani tes Rapid maupun tes $S w a b$, ia juga menjelaskan bahwa selama proses penyidikan itu banyak sekali mengalami penundaan baik itu penundaan yang dikarenakan keadaan yang mendesak seperti COVID-19 maupun penundaan yang tidak ada penjelasan yang diberikan kepada dia, ia pun hanya dapat menerima dengan segala yang diberlakukan kepadanya. Menurut Ayu (tahanan jaksa) yang merupakan tahanan dengan kasus (Penggelapan Dalam Jabatan) yang berasal dari kota Medan Sumatera Utara, dan ia ditetapkan sebagai tahanan jaksa pada tanggal 17 Maret 2021, selama menjadi tahanan jaksa ia tetap ditempatkan di Kantor Kepolisian Resor Kota Lhokseumawe dan digabung dengan tahanan yang lainnya. (jaksa), 2021)

Dengan fakta tersebut bagaimana protokol kesehatan untuk melakukan jaga jarak (Social Distancing) akan dilaksanakan, serta belum lagi terhadap tahanan A3 (tahanan hakim) yang positif COVID-19, walaupun sudah berstatus tahanan A3 jika hasil tes Rapid tetap menunjukan Positif COVID maka tahanan tetap akan dititipkan di sel tahanan Kantor Kepolisian Resor Lhokseumawe.

\section{Kurangnya pengetahuan tersangka/terdakwa mengenai pengalihan jenis penahanan dan pembantaran penahanan}

Dalam rangka pencegahan penumpukan tahanan di dalam sel tahanan Kantor Kepolisian, bisa saja tersangka/terdakwa meminta untuk dilakukan pengalihan jenis penahanan ataupun pembantaran penahanan, namun kurangnya pemahanan dan pengetahuan mengenai hal tersebut menyebabkan para tahanan tidak ada yang meminta untuk dilakukannya pengalihan jenis penahanan, penangguhan penahanan ataupun pembantaran penahanan bagi tahanan yang memiliki penyakit yang membutuhkan penanganan medis yang serius (COVID-19), serta juga kurangnya sosialisasi dan edukasi dari aparatur penegak hukum dalam memberikan pengetahuan mengenai hal tersebut, sehingga penumpukan tahanan di sel tahanan Kantor Kepolisian terus saja terjadi.

Menurut Kardono, dijelaskan permintaan pengalihan jenis penahanan ataupun pembantaran itu harus diminta langsung oleh pihak tersangka/terdakwa dengan syarat adanya uang jaminan dan adanya orang yang bisa dijadikan sebagai penjamin, jika hal tersebut tidak terpenuhi maka, pengalihan ataupun pembantasan tidak bisa dilakukan. (Kardono, 2021)

\section{Penyelesaian Persoalan Penahanan Dimasa Pandemi COVID-19}

Penahanan memang penting untuk dilakukan, apalagi terhadap kasus-kasus yang memerlukan pembuktian yang lebih jauh dan terhadap kasus yang ancaman hukumannya diatas 5 (lima) tahun penjara. Selama masa pandemi COVID-19, sebenarnya Kementerian Hukum dan Ham juga merekomendasikan beberapa opsi untuk mencegah terjadinya kelebihan kapasitas (overcrowding) di dalam Rutan atau Lapas, yang salah satunya adalah pengalihan jenis penahanan. Baik itu dialihkan ke tahanan kota, tahanan rumah maupun terhadap tahanan yang memerlukan penanganan khusus untuk penyakitnya bisa saja dilakukan pembantaran penahanan. 
Pengalihan jenis tahanan bisa saja untuk dilakukan sebagai salah satu opsi jika Rutan dan Lapas yang ada sudah mengalami kelebihan kapasitas (overcrowding), dan tentu saja hal ini dapat mencegah menumpuknya tahanan di dalam sel Rutan atau Lapas selama masa pandemi COVID-19. Dalam Surat Jaksa Agung Republik Indonesia tahun 2020 yang salah satu isinya untuk mempertimbangkan untuk pemberian mengalihan atau penangguhan penahanan dengan mempedomani ketentuan Pasal 21 dan Pasal 22 KUHAP dan setelah melalui konsultasi dengan pimpinan satuan kerja.

a. Pengalihan Jenis Tahanan

Seorang tahanan yang dikenakan salah satu jenis penahanan yang terdapat dalam Pasal 22 KUHAP bisa saja dialihkan jenis penahanannya oleh pejabat yang berwenang yang secara yuridis terhadap tahanan tersebut, baik itu penyidik, penuntut umum maupun hakim. Misalnya tahanan yang dikenakan tahanan Rutan bisa saja dialihkan kejenis tahanan kota atau tahanan rumah begitu juga sebaliknya. Pengalihan jenis penahanan berdasarkan Pasal 23 KUHAP juga harus memenuhi persyaratan tertentu dan harus dinyatakan secara tersendiri dengan surat perintah dari penyidik, penuntut umum maupun hakim dan surat perintah pengalihan jenis penahanan tersebut haruslah ditembuskan kepada tersangka atau terdakwa serta keluarga dan instansi yang berkepentingan lainnya. (Renggong, 2014)

Jika diliat berdasarkan keterangan diatas inisiatif pengalihan jenis tahanan itu berasal dari penyidik, penuntut umum serta hakim, namun dalam prakteknya dilapangan yang meminta untuk dilakukan pengalihan jenis penahanan adalah tersangka atau terdakwa dengan kesediaan memenuhi persyaratan berupa adanya jaminan uang dan/ atau orang, dan apabila pengalihan jenis penahanan itu dilakukan oleh warga negara asing maka surat perintah atau penetapan hakim tersebut secara analogi harus diberikan kepada perwakilan negaranya.

b. Pembantaran Penahanan

Pembantaran atau yang dalam hukum pidana lebih dikenal dengan Pembantaran Penahanan, merupakan penundaan penahanan sementara terhadap tersangka atau terdakwa karena alasan kesehatan yang dapat dikuatkan dengan keterangan Dokter sampai dengan yang bersangkutan dinyatakan sembuh kembali. Mengenai hak tahanan untuk dilakukan pembantaran selama kondisi kesehatan tahanan dianggap membahayakan maka pembantaran harus dilakukan ini berkaitan dengan Hak Asasi Manusia.

c. Pembangunan Lapas baru

Dengan dibangunnya Lapas yang baru tentu saja dapat menangani permasalahan tentang penempatan tahanan selama masa pandemi sekarang ini, dan tentunya dapat mengindari penyebaran virus COVID-19 didalam lingkup UPT Pemasyarakatan itu sendiri, hal ini juga sejalan dengan rencana dari Kementerian Hukum dan HAM Kantor Wilayah Aceh yang berencana untuk membangun Lapas yang baru pada wilayah hukum Lhokseumawe, yang mana rencana pembangunan ini ditujukan untuk mengurangi overcrowding di Lapas Kelas II A dan untuk daya tampung Lapas yang baru adalah 600 
jiwa. Namun pembangunan Lapas yang baru untuk sekarang belum dimulai proses pembangunannya baru masuk tahap perencanaan. (Aceh, 2021)

\section{KESIMPULAN}

Berdasarkan hasil tulisan di atas dapat disimpulkan bahwa:

Mengenai kewenangan untuk dilakukan atau tidaknya suatu penahanan merupakan hak prerogatif dari seoang penyidik, penuntut umu dan hakim sesuai dengan tahapan pemeriksaannya masing-masing. Dan untuk Surat Edaran Menteri Hukum Dan HAM tentang kebijakan penundaan sementara pengiriman tahanan ke dalam Rutan/Lapas selama Masa Pandemi COVID-19 untuk Wilayah Hukum Kota Lhokseumawe sendiri dijalankan sejak tanggal 15 Oktober 2020 dan Mengenai tahanan yang tidak dapat dikirim kedalam Rutan/Lapas selama adalah Tahanan A1 (Tahanan Penyidik) dan Tahanan A2 (Tahanan Jaksa) dan Tahanan yang dapat dikirm kedalam Lapas adalah Tahanan A3 ( Tahanan Hakim) yang telah memenuhi persyaratan dalam hal ini adalah sudah adanya hasil Tes $S W A B$ yang menyatakan terdakwa bebas dari COVID-19 serta adanya ketetapan dari hakim Pengadilan Itu sendri. Dan Hambatan dalam pelaksanaan kebijakan tersebut adalah jumlah Blok/ sel tahanan yang tidak mencukupi di Kantor Kepolisian, serta membludaknya jumlah tahanan selama masa pandemi, dan kekurangannya jumlah penjaga dalam melakukan pengawasan, serta tidak dilakukannya pengalihan, serta pembantaran penahanan dalam rangka pencegahan penyebaran virus COVID-19.

\section{SARAN}

Berdasarkan hasil tulisan diatas maka penulis memberikan saran sebagai berikut:

Kepada pemerintah untuk kedepannya dapat memasukan sistem hakim pemeriksaan (Judicial Scrutiny) dalam rancangan KUHAP, sehingga adanya mekanisme kontrol dan pengawasan yang ketat dan mendetail mengenai penahanan itu sendiri. Dan untuk segera dilaksanakan pembangunan Lapas yang baru sehingga tidak terjadi kelebihan kapasitas (overcrowding) di situasi yang seperti ini sekarang, sehingga penyebaran virus COVID-19 dapat dicegah baik itu di dalam Rutan/Lapas.

\section{DAFTAR PUSTAKA}

Barda Nawawi Arief, 2010, Bunga Rampai Kebijakan Hukum Pidana, PT Citra Adityta Bakti, Bandung.

Budiansyah Arief, 16 Maret 2020, Apa itu Virus Corona Dan Apa Cirinya Menurut WHO, www.cnbindonesia.com , Diakses Pada 22 Desember 2020 Pukul 18:56 Wib.

Endrik Safudin, 2017, Dasar-Dasar Ilmu Hukum, Setara Press, Malang.

Muhammad Sadi, 2015, Kumpulan Hukum Acara Di Indonesia, Prenadamedia Group, Jakarta.

Ruggong Ruslan, 2021, Hukum Acara Pidana Cetakan Ke-3, Kencana, Jakarta

Republik Indonesia, Undang-Undang Nomor 8 Tahun 1981 Tentang Kitab UndangUndang Hukum Acara Pidana.

Republik Indonesia, Undan -Undang Nomor 12 Tahun 1995 Tentang Pemasyarakatan 
Republik Indonesia, Peraturan Pemerintah Nomor 27 Tahun 1983 Tentang Pelaksanaan Kitab Undang-Undang Hukum Acara Pidana.

Sasangka Hari dan Rosita Lyli, 2003, Komentar Kitab Undang-Undang Hukum Acara Pidana, Mandar Maju, Bandung.

Surat Edaran Menteri Hukum dan HAM, Nomor:M.HH.PK.01.01.01-04 Tentang penundaan sementara pengiriman tahanan ke Rutan/lapas di lingkungan kemenkumham.

Surat Edaran Kementerian Hukum dan HAM Kantor Wilayah Aceh, Nomor:W1PK.01.01.086 Tentang Prihal Pencegahan Penyebaran Wabah ViRUS covid-19 Ke Dalam Lapas/Rutan.

Surat Edaran Direktur Jenderal Pemasyarakatan, Nomor:PAS-PK.01.01.01-511 Tentang Registrasi Dan Pemberian Makanan Tahanan (A2) Di Luar Rutan/Lapas/LPKA.

Surat Edaran Direktur Jenderal Pemasyarakatan, Nomor:PAS-PK.01.01.750 Tentang Penerimaan Tahanan Pengadilan (A3).

Surat Edaran Direktur Jenderal Pemasyarakatan, Nomor:PAS-OT.02.02.25 Tentang Revisi 1 Pedoman COVID-19 Di UPT Pemasyarakatan.

Surat Edaran Direktur Jenderal Pemasyarakatan, Nomor:PAS-20.PR.01.01.2020 Tentang Langkah Progresif Dalam Penanggulangan Penyebaran Virus COVID-19 Pada Unit Pelaksanaan Teknis Pemasyarakatan.

Surat Edaran Direktur Jenderal Pemasyarakatan, Nomor:PAS7.01.06.06-190 Tentang Kewajiban Pelaksanaan Protokol Kesehatan Dalam Rutan/Lapas Selama Pandemi COVID-19.

Sistem Database Pemasyarakatan, Smslap.dirjenpas.go.id, Daftar Rutan Dan Lapas Yang Ada Di Provinsi Aceh, Diakses Pada 25 Maret 2021 Pada Pukul 19:20 Wib

Sistem Database Pemasyarakatan, Smslap.dirjenpas.go.id, Data Terakhir Jumlah Penghuni Per UPT Pada KANWIL Aceh, Diakses Pada 26 Maret 2021 Pada Pukul 18:12 Wib 